\title{
HUBUNGAN ANTARA KECERDASAN EMOSIONAL DENGAN INTENSI BERWIRAUSAHA PADA SISWA SMK NEGERI 44 JAKARTA
}

\author{
Khoerunnisa \\ Alumni Fakultas Ekonomi Universitas Negeri Jakarta \\ Nuryetty Zain \\ Dosen Fakultas Ekonomi Universitas Negeri Jakarta
}

\begin{abstract}
This research has purpose to get valid and reliable data about the relationship between emotional quotient and entrepreneurial intention on students 44 State Vocational High School in Jakarta. The research was conducted by survey method with correlational approach. The population in this research were all students at 44 State Vocational High School in Jakarta. Affordable population in this research were the students in XI Departement Administrative office, Accounting, and Marketing amount to 192 students. Total of samples used were 123 students research. Sampling technique used in the form of a questionnaire with 30 statements to variable of emotional quotient and 24 statements to variabel of entrepreneurial intention. From requirement analysis test conducted, the data is normally distributed by linier regretion equation $Y=58,04+0,55 X$. By calculating the correlation coefficient for emotional quotient $(X)$ to entrepreneurial intention $(Y)$ was 0,4276 which is shows that the correlation is strong. Base on calculation of the coefficient determination was obtained 0,1828 or $18,28 \%$. It showed that $18,28 \%$ of emotional quotient affect studens entrepreneurial intention, while the remaining $81,78 \%$ is influenced by other variables that are not described in this model.
\end{abstract}

Key words : Entrepreneurial Intention, Emotional Quotient

\section{PENDAHULUAN}

\section{A. Latar Belakang Masalah}

Permasalahan tenaga kerja di

Indonesia akhir-akhir ini semakin kompleks. Hal ini dapat di amati dari jumlah pengangguran yang terus meningkat dan terbatasnya lapangan kerja saat ini. Pengangguran yang terjadi merupakan lulusan jenjang pendidikan SMA, SMK, dan perguruan tinggi. Dari tahun ke tahun populasi pengangguran di Indonesia bukanya menurun tetapi semakin bertambah mengingat pertumbuhan penduduk tahun ke tahun makin meningkat, sementara lapangan pekerjaaan yang tersedia semakin sempit.
Dari data Departemen Pendidikan Nasional menunjukkan bahwa setiap tahunnya tidak kurang dari 1.450.498 siswa SMA/SMK yang lulus (Djumena 2009), belum lagi ditambah jumlah mahasiswa yang lulus dari perguruan tinggi. Hal tersebut mengakibatkan ketidakseimbangan antara jumlah lulusan dengan daya serap tenaga kerja. Berdasarkan data yang didapatkan dari Badan Pusat Statistik (BPS, 2011) saat ini sebagian besar angka pengangguran didominasi oleh lulusan Sekolah Menengah Atas (SMA) sebesar 12,17\%, lalu lulusan Diploma sebesar 11,59\%, kemudian sebanyak $10 \%$ oleh lulusan 
Sekolah Menengah Kejuruan (SMK), di ikuti Perguruan Tinggi sebanyak 9,95\%, Sekolah Menengah Pertama (SMP) 7,83\%, dan Sekolah Dasar (SD) 3,37\%.

Sangat disayangkan jika para pelajar yang telah menempuh pendidikan yang cukup baik namun pada akhirnya hanya menjadi pengangguran, terutama siswa lulusan SMK yang saat ini menjadi penyumbang terbesar ketiga angka penganguran yang mencapai 8,12 juta orang pada Februari 2011 (BPS, 2011).

Padahal SMK merupakan sekolah yang memiliki kurikulum serta program pendidikan yang terfokus pada pembekalan keterampilan guna mempersiapkan siswanya untuk siap turun dan bersaing di dunia kerja setelah lulus sekolah, karena setiap siswa sudah dibekali dengan berbagai macam keahlian.

Sejak tahun 1994 pemerintah melalui Departemen Pendidikan Nasional mulaimenerapkan standarisasi kurikulum pada seluruh SMK, yaitu kewajiban mengajarkan mata pelajaran kewirausahaan (Depniknas, 2011). Dengan modal keterampilan dan pengetahuan yang didapatkan siswa dari sekolah serta ditambah dengan pengetahuan kewirausahaan dari mata pelajaran kewirausahan yang mereka dapatkan selama menempuh pendidikan di tingkat SMK. Dengan begitu siswa lulusan SMK tidak hanya menjadi seorang pencari kerja namun dapat menjadi seorang pembuka lapangan kerja atau seorang pengusaha. Dengan berwirausaha ia dapat mandiri, serta dapat membantu membuka lapangan pekerjaan bagi orang lain.

Namun kenyataanya, dunia wirausaha belum menjadi pilihan para siswa sebagai karir masa depan mereka salah satu nya adalah para siswa SMK Negeri 44 Jakarta. Kecenderungan yang terjadi pada lulusan Sekolah Menengah
Kejuruan saat ini adalah mencari pekerjaan di kantor maupun di pertokoan. Tinggi rendahnya keinginan siswa untuk berwirausaha dapat dimaknai sebagai tinggi-rendahnya intensi berwirausaha siswa.

Fenomena yang terjadi saat ini adalah siswa yang mengurungkan niatnya dalam berwirausaha karena teman-teman terdekatnya tidak berminat untuk menjadi seorang wirausaha. Hal ini tentu saja sangat disayangkan karena suatu keinginan yang baik tidak dilakukan hanya karena dukungan sosial yang berada disekitarnya tidak mendukung.

Selain itu banyak siswa menganggap bahwa menjadi wirausaha yang merintis usaha baru tentu akan menghadapi suatu keberhasilan dan kegagalan. Mereka merasa ragu-ragu untuk memulai suatu usaha karena takut akan kegagalan. Sebenarnya kegagalan merupakan proses untuk menjadi sukses, dimana seorang wirausaha tidak akan sukses jika belum mengalami kegagalan. Seorang wirausaha harus berani menanggung resiko, dengan begitu akan memberikan kesadaran kepada mereka bahwa hidup ini adalah perjuangan yang harus dihadapi dan harus gigih dalam mempertahankan kelangsungan hidup.

Kondisi ini diakibatkan karena kecerdasan emosional siswa yang rendah untuk menjadi seorang wirausaha. Salah satu aspek terpenting dalam kecerdasan emosional adalah kesadaran diri. Seseorang yang memiliki kesadaran diri yang baik akan mampu memotivasi dirinya sendiri, menunjukkan inisiatif, mempunyai dorongan batin untuk berusaha lebih keras serta cukup optimis ketika menghadapi kegagalan.

Dengan kecerdasan emosional yang tinggi, seseorang akan mampu meningkatkan motivasi dirinya untuk bekerja lebih keras, belajar mandiri, 
berkepribadian kuat, berpikir positif dan tidak mudah putus asa. Kemampuan ini tentu akan menumbuhkan intensi seseorang dalam merintis suatu usaha. Untuk menjadi wirausaha diperlukan kecerdasan emosional, karena suatu keberhasilan salah satunya ditentukan oleh kecerdasan emosi yang dimiliki seseorang.

Seorang wirausaha yang memiliki keceerdasan emosional yang optimal memiliki peluang lebih untuk mencapai puncak keberhasilan, peka terhadap peluang serta akan mampu menghadapi konflik yang akan dihadapi. Bahkan ada pakar yang mengatakan bahwa keberhasilan seseorang dalam bidang bisnis, $80 \%$ nya ditentukan oleh kecerdasan emosionalnya.

\section{Perumusan Masalah}

Dari pembatasan masalah di atas, masalah dapat dirumuskan sebagai berikut "Apakah terdapat hubungan antara kecerdasan emosional dengan intensi berwirausaha pada siswa?

\section{KAJIAN TEORETIK}

\section{A. Deskripsi Konseptual \\ 1. Intensi Berwirausaha}

Seorang wirausaha biasanya selalu mengejar peluang-peluang yang ada, memasuki pasar-pasar baru, serta menawarkan produk-produk baru. Hal ini merupakan bagian dari suatu proses yang tidak disengaja, proses yang tidak disengaja tersebut adalah intensi atau niatan. Intensi didefinisikan olen Robert D. Hisrich (2004) sebagai berikut :

Intensi menunjukkan faktor-faktor motivasional yang mempengaruhi perilaku dan merupakan indikasi-indikasi tentang betapa sulitnya orang-orang bersedia untuk berusaha, serta seberapa banyak upaya yang mereka rencanakan untuk digunakan dalam melaksanakan perilaku tersebut.
Pengertian tersebut menyatakan bahwa intensi merupakan faktor motivasional yang memiliki sebuah akibat pada perilaku, dengan mengindikasikan seberapa keras keinginan untuk mencoba, seberapa banyak berusaha dalam merencanakan yang semuanya bertujuan pada sebuah tingkah laku. Pada umumnya, semakin kuat intensi untuk terlibat dalam sebuah perilaku, semakin besar kemungkinan hal itu dilaksanakan. Fishbein dan Ajzen (2005) mengartikan intensi merupakan "komponen dalam individu yang mengacu pada keinginan untuk melakukan tingkah laku tertentu"

Dalam sebuah penelitian, Bandura dalam Wijaya (2005) menyatakan bahwa "intensi merupakan suatu kebulatan tekad untuk melakukan aktivitas tertentu ataumenghasilkan keadaan tertentu dimasa depan". Dari definisi diatas dapat disimpulkan bahwa intensi merupakan seberapa besar keinginan seseorang untuk melakukan suatu perilaku dan aktivitas tertentu yang nantinya akan dilaksanakan. Menurut Borsch (2011) Intensi memiliki tiga dimensi yaitu :

a. Sikap terhadap perilaku

b. Norma subjektif

c. Kontrol atas perilaku

Individu yang memiliki keyakinan yang positif terhadap suatu perilaku akan memiliki kecenderungan untuk melakukan tindakan tersebut. Atau dengan kata lain, sikap yang mengarah pada perilaku ditentukan oleh konsekuensi yang ditimbulkan oleh perilaku, yang disebut dengan istilah keyakinan terhadap perilaku.

Keyakinan yang mendasari norma subjektif yang dimiliki individu disebut sebagai keyakinan normatif. Individu memiliki keyakinan bahwa individu atau kelompok tertentu akan menerima atau tidak menerima tindakan yang dilakukannya. Apabila individu 
meyakini apa yang menjadi norma kelompok, maka ia akan mematuhi dan membentuk perilaku yang sesuai dengan kelompoknya. Dapat disimpulkan bahwa norma kelompok inilah yang membentuk norma subjektif dalam diri individu, yang akhirnya akan membentuk perilakunya.

Sedangkan kontrol perilaku merupakan keyakinan tentang ada atau tidaknya faktor-faktor yang memfasilitasi dan menghalangi performansi perilaku individu. Kontrol perilaku ditentukan oleh pengalaman masa lalu dan perkiraan individu mengenai seberapa sulit atau mudahnya untuk melakukan perilaku yang bersangkutan.

Kewirausahaan mulai dikenal secara populer pada abad ke-18. Seorang Irlandia bernama Richard Cantillon yang berdiam di Perancis merupakan orang yang pertama menggunakan istilah "wirausaha" di dalam bukunya Essai Sur la Nature du Commerce en Generale (terjemahan). Dalam bukunya tersebut ia menjelaskan bahwa wirausaha adalah seorang yang menanggung resiko. Pada awalnya istilah wirausaha sebutan bagi para pedagang yang membeli barang kemudian menjualnya dengan harga yang tidak pasti. Namun istilah tersebut berkembang seiring perkembangan ilmu pengetahuan. Menurut Instruksi Presiden RI No.4 tahun 1995 "kewirausahaan adalah semangat, sikap, perilaku, dan kemampuan seseorang dalam menangani usaha dan atau kegiatan yang mengarah pada upaya mencari, menciptakan, menerapkan cara kerja, teknologi, dan produk baru dengan meningkatkan efisiensi dalam rangka memberikan pelayanan yang lebih baik dan atau memperoleh keuntungan yang lebih besar

Lebih lanjut David E. Rye dalam Borsch (2011) menambahkan bahwa "wirausaha adalah seorang yang mengorganisasikan dan mengarahkan usaha baru. Wirausaha berani mengambil risiko yang terkait dengan proses pemulaian usaha". Dari kedua pengertian diatas maka dapat disimpulkan bahwa kewirausahaan merupakan hal-hal atau upaya yang berkaitan dengan penciptaan kegiatan atau usaha atau aktivitas bisnis atas dasar kemauan dan kemampuan sendiri dengan berani mengambil resiko serta mendapatkan keuntungan yang besar. Intensi berwirausaha menurut Katz dan Gartner dalam Wong (2006) "entrepreneurial intention as the search for infrmation that can be used to help fulfil the goal of venture creation" dapat diartikan sebagai "proses pencairan informasi yang dapat

digunakan untuk mencapai tujuan pembentukan suatu usaha. Selanjutnya menurut Soumya Sagiri (2009) menyatakan "Entrepreneurial intentions are derived through perceptions of feasibility and desirability and proclivity to act up on opportunities"Dapat diartikan intensi berwirausaha berasal dari persepsi kelayakan dan keinginan dan kecenderungan untuk bertindak diatas peluang.

Berdasarkan teori tersebut maka intensi berwirausaha merupakan suatu proses untuk mencapai pembentukan suatu usaha dengan bentindak melihat peluang yang ada.

Keith Perks dalam Sata (2013) mengatakan "Entrepreneurial intention defined as an individulas proclivity and desire to become an entrepreneur" yang dapat diatrikan intensi berwirausaha didefinisikan sebagai kecenderungan dan keinginan seseorang untuk menjadi wirausahawan. Pengertian yang sama menurut Kolvereid dan McStay intensi berwirausaha "entrepreneurial intention is defined as an individual's intention to be self employee". Jika diartikan intensi berwirausaha didefinisikan sebagai niat 
seseorang untuk menjadi wirausaha.

Sementara menurut Wijaya (2007),

Intensi kewirausahaan dapat diartikan sebagai niat atau keinginan yang ada pada diri seseorang untuk melakukan suatu tindakan wirausaha. Dari pendapat para ahli tersebut dapat disimpulkan bahwa intensi berwirausaha merupakan kecenderungan dan keinginan seseorang untuk menjadi wirausaha dengan melakukan suatu tindakan kewirausahaan.

Teori selanjutnya menurut Fransisco Linan(2006) "an entrepreneurial intentions is would be argue that individuals makes their creation decision based on three elements, his personal preference or attraction towards entrepreneurship, the perceived social norm regarding that career option, and thirdly, his perceived entrepreneurial self efficacy". Dapat diartikan bahwa intensi berwirausaha adalah keputusan individu untuk berwirausaha yang berasal dari preferensi pribadi, norma sosial, dan keyakinan pada dirinya.

Definisi intensi berwirausaha lainnya dikemukakan oleh Bird dalam Linan (2006) “an antrepreneur's intentions to start a business and the decisions that occur before start up shape the subsequent goals, strategies, and structures of the new venture". Dapat diartikan bahwa intensi wirausaha adalah keputusan seseorang sebelum memulai bisnis, dan strategi dari usaha baru yang akan dibuatnya.

Menurut Riccardo fini (2009) menjelaskan "we define entrepreneurial intention as a cognitive of the actions to be implemented by individuals to either establish new independent ventures or to create new value within existing companies".Jika diartikan kami mendefinisikan intensi berwirausaha sebagai representasi kognitif tindakan yang akan dilaksanakan oleh individu baik mendirikan usaha baru yang independen atau untuk menciptakan nilai baru dalam perusahaan yang sudah ada.

Sementara menurut Costa \& McCrae dan Holland (Jeff Brice, JR, 2003) menganggap orang yang positif memiliki keinginan berwirausaha dan telah sejak lama memiliki hubungan kuat dengan kegiatan kewirausahaan. Dari kedua definisi tersebut maka intensi berwirausaha adalah keinginan seseorang untuk menjadi wirausahawan baik dengan cara mendirikan sebuah usaha dengan menciptakan nilai baru dan melaksanakan kegiattan kewirausahaan.

Dari beberapa teori diatas, maka dapat ditarik kesimpulan, intensi berwirausaha merupakan keinginan serta keputusan individu untuk menjadi wirausahawan dengan melakukan kegiatan kewirausahaan, menciptakan nilai baru dari usaha yang sudah ada, serta menetukan strategi yang akan dilakukan dalam memulai usaha tersebut.

\section{Kecerdasan Emosional}

Menurut Sunar

Kecerdasan emosional atau yang biasa dikenal dengan EQ adalah kemampuan seseorang untuk menerima, menilai, mengelola, serta mengontrol emosi dirinya dan orang lain di sekitarnya. Belakangan ini kecerdasan emosional dinilai tidak kalah penting dengan kecerdasan lainnya seperti kecerdasan intelektual (IQ). Sebuah penelitian mengungkapkan bahwa kecerdasan emosional dua kali lebih penting daripada kecerdasan intelektual dalam memberikan konstribusi terhadap kesuksesan seseorang.

Menurut Salovey dan Mayer dalam Sunar (2010) mendefinisikan "kecerdasan emosi sebagai kemampuan memantau dan mengendalikan emosi sendiri dan orang lain, serta menggunakan 
emosi itu untuk memandu pikiran dan tindakan". Sedangkan Daniel Goleman mengartikan kecerdasan emosional sebagai kemampuan untuk memotivasi diri sendiri dan bertahan menghadapi frustasi, mengendalikan dorongan hati dan tidak melebih-lebihkan kesenangan, mengatur suasana hati dan menjaga agar beban stress tidak melumpuhkan kemampuan berpikir, berempati dan berdoa.

Dari definisi diatas dapat disimpulkan bahwa kecerdasan emosional merupakan kemampuan seseorang untuk bisa mengendalikan emosi sendiri dan orang lain yang digunakan baik untuk memotivasi diri sendiri, memandu pikiran dan tindakan, serta mengendalikan suasana hati.

Seseorang dengan kecerdasan emosional yang baik cenderung lebih mampu mengendalikan amarah dan bahkan mengarahkan energinya kearah yang lebih positif, bukan kearah ekspresi yang negatif atau destruktif. Sebaliknya, seseorang dengan taraf kecerdasan emosional yang rendah mungkin bertindak eksplosif dan destruktif ketika merasa kecewa.

Hal ini diperjelas oleh Steven J Stein dan Horward E. Book (2010) menjelaskan pendapat Peter Salovey dan John Mayer, bahwa kecerdasan emosional adalah kemampuan untuk mengenali perasaan, meraih dan dan membangkitkan perasaan untuk membantu pikiran, memahami perasaan dan maknanya, dan mengendalikan perasaan secara mendalam sehingga membantu perkembangan emosi dan intelektual. Begitu juga Davies menambahkan, bahwa kecerdasan emosional adalah kemampuan seseorang untuk mengendalikan emosi dirinya sendiri dan orang lain, membedakan satu emosi dengan lainnya, dan menggunakan informasi tersebut untuk menuntun proses berpikir serta perilaku seseorang

Berdasarkan kedua definisi tersebut, dapat disimpulkan bahwa kecerdasan emosional merupakan kemampuan seseorang dalam mengendalikan perasaan yang berupa emosi dalam diri dalam proses berpikir dan berperilaku dikehidupan sehari-hari.

Reuven Bar-on dalam Uno (2007)

menjelaskan bahwa "kecerdasan emosional adalah Serangkaian kemampuan, kompetensi, dan kecakapan nonkognitif yang mempengaruhi kemampuan seseorang untuk berhasil mengatasi tuntutan dan tekanan lingkungan"

Sejalan dengan Monty P Satiadarma \& Fidelis E Waruwu (2003) yang menyatakan kecerdasan emosi dibutuhkan oleh semua pihak untuk dapat hidup bermasyarakat termasuk di dalamnya menjaga hubungan sosial, dan hubungan sosial yang baik akan mampu menuntun seseorang untuk memperoleh sukses di dalam hidup seperti yang diharapkan. Disamping itu, kemampuan seseorang untuk mengendalikan emosinya dengan baik akan mempengaruhi proses berpikirnya secara positif pula.

Dari kedua definisi tersebut maka dapat disimpulkan bahwa seseorang yang memiliki kecerdasan emosional yang baik akan mempengaruhi tingkat kemampuan seseorang dalam menghadapi tuntutan atau tantangan dalam hidup, dan jika berhasil dalam mengendalikan emosinya maka akan selalu berpikir secara positif dalam menghadapi sesuatu.

Dari beberapa teori diatas, maka dapat ditarik kesimpulan kecerdasan emosional merupakan kemampuan seseorang untuk mengenali emosi diri, mengelola emosi, memotivasi diri, mengenali emosi orang lain (empati), dan kemampuan untuk membina hubungan dengan orang lain. 


\section{Kerangka Teoretik}

Intensi berwirausaha merupakan keingian individu untuk memutuskan menjadi seorang wirausaha Menurut Daniel Goleman (2005) untuk menjadi seorang wirausaha yang sukses tidak semata memerlukan intelegensi (IQ) saja, namun dibutuhkan pula Emotional quotient atau kecerdasan emosi. Bukan hanya kecerdasan intelektual saja yang menentukan seseorang untuk menjadi wirausaha tetapi dibutuhkan juga kecerdasan emosional. Sama halnya menurut Dwi Sunar (2010) dalam bukunya menyatakan bahwa kecerdasan emosi mutlak dibutuhkan oleh para calon entrepreneur. Karena kesuksesan bisnis berkaitan langsung dengan kecerdasan emosi.

$$
\text { Dalam hasil penelitian }
$$
sebelumnya oleh Irene Paulina dan Wardoyo(2012) menyebutkan dengan memiliki kecerdasan emosi, seseorang akan mampu mengenali dirinya dan kemampuan dirinya yang dapat menimbulkan niatan (intensi) seseorang untuk melakukan suatu jenis usaha.

Dalam penelitian Povilas Zakarevicius and Aurimas Zuperka (2010) menyatakan

"On the basis of the attitudes of the mentioned authors the assumption may be done, that emotional intelligence of an individual is an important element as the capability of entrepreneurial intentions". Dapat diartikan Atas dasar sikap penulis mengasumsikan bahwa kecerdasan emosional seorang individu merupakan elemen penting sebagai kemampuan niat kewirausahaan.

Selanjutnya Zampetakis L.A., et al.,(2009) model (fig. 1) "shows that emotional components are expressed by feelings and emotions, determining attitude toward own entrepreneurial intentions" bahwa komponen emosional yang diungkapkan oleh perasaan dan emosi, menentukan sikap terhadap niat kewirausahaan).

Hasil penelitian selanjutnya dalam The study carried out by Zampetakis L.A., et al.,(2009) "states the entrepreneurial intentions as the result of emotional intelligence. Studi yang dilakukan oleh Zampetakis LA, et al., (2009) menyatakan niat kewirausahaan sebagai hasil dari kecerdasan emosional. Dari teori-teori diatas menyatakan bahwa dengan memiliki kecerdasan emosional maka akan menimbulkan keingian seseorang untuk memulai suatu usaha. Karena kecerdasan emosional merupakan elemen penting bagi keberhasilan seseorang dalam menentukan masa depannya.

\section{Perumusan Hipotesis Penelitian}

Dugaan sementara berdasarkan deskripsi konseptual dan kerangka teoritik, maka hipotesis penelitian ini adalah terdapat hubungan antara kecerdasan emosional dengan intensi berwirausaha pada siswa SMK N 44 Jakarta. Makin tinggi kecerdasan emosional maka makin tinggi pula intensi berwirausahanya.

\section{METODOLOGI PENELITIAN}

\section{Tujuan Penelitian}

Berdasarkan masalah-masalah yang telah peneliti rumuskan, maka tujuan penelitian ini adalah untuk mendapatkan pengetahuan yang tepat tentang hubungan antara kecerdasan emosional dengan intensi berwirausaha pada siswa.

\section{Tempat dan Waktu Penelitian}

Penelitian dilaksanakan di wilayah Jakarta Pusat, tepatnya di SMK Negeri 44 yang beralamat di J1. Harapan Jaya 9/5A Kemayoran, Jakarta Pusat. SMK Negeri 44 dipilih karena ingin 
mengetahui apakah siswa/siswi nya memiliki motivasi yang kuat terhadap intensi berwirausaha dengan meliat peluang-peluang yang ada dilingkungan mereka, yang sebagian besar berasal dari keluarga ekonomi menegah ke bawah.

Waktu penelitian dilaksanakan selama 3 bulan, yakni dari bulan April sampai dengan bulan Juni 2014. Alasan memilih waktu tersebut karena merupakan waktu yang paling efektif bagi peneliti untuk melakukan penelitian.

\section{Metode Penelitian}

Metode yang digunakan dalam penelitian ini adalah metode survey dengan pendekatan korelasional. Menurut Sugiyono, metode survey digunakan untuk mendapatkan data dari tempat tertentu yang alamiah (bukan buatan), tetapi peneliti melakukan perlakuan dalam pengumpulan data, misalnya dengan mengedarkan kuesioner, test, wawancara tersetruktur dan sebagainya (perlakuan tidak seperti eksperimen).

$$
\text { Populasi adalah wilayah }
$$
generalisasi terdiri atas obyek atau subyek yang mempunyai kualitas dan karakteristik tertentu ditetapkan oleh peneliti untuk dipelajari dan kemudian ditarik kesimpulannya (Sugiyono, 2001). Populasi dalam penelitian ini adalah seluruh siswa di SMK Negeri 44 Jakarta Pusat Tahun Ajaran 2013/2014. Adapun populasi terjangkaunya yaitu siswa kelas XI Jurusan Adm. Perkantoran, Akuntansi, dan Pemasaran yang berjumlah 192 siswa. Peneliti memilih kelas XI sebagai populasi tejangkau karena peneliti ingin melihat bagaimana para siswa mengelola kecerdasan emosional nya yang akan berdampak pada intensi berwirausaha siswa. Sedangkan Sampel adalah sebagian dari populasi yang menjadi obyek penelitian atau yang dijadikan responden (Santoso dan Tjiptono, 2002). Berdasarkan tabel Isaac Michael, sampel penentuan taraf kesalahan 5\% diperoleh sampel sebanyak 123 siswa.

\section{Intensi Berwirausaha (Variabel Y) \\ a. Definisi Konseptual}

Intensi berwirausaha merupakan keinginan serta keputusan individu untuk menjadi wirausahawan dengan cara memulai usaha serta menetukan strategi yang akan dilakukan dalam memulai usaha tersebut.

\section{b. Definisi Operasional}

Intensi berwirausaha mempunyai dua indikator yaitu keinginan menjadi wirausaha dan keputusan untuk berwirausaha. Sub indikator dari keinginan menjadi wirausaha adalah kegiatan kewirausahaan dan menciptakan nilai baru, sedangkan sub indikator dari keputusan untuk berwirausaha adalah memulai usaha dan strategi untuk usaha baru. Setiap butir pertanyaan diberi skor sesuai dengan model skala Likert, seperti tampak dalam tabel berikut ini:

\section{Kecerdasan Emosional (Variabel X) a. Definisi Konseptual}

Kecerdasan emosional merupakan kemampuan seseorang untuk mengenali emosi diri, mengelola emosi, memotivasi diri, mengenali emosi orang lain (empati), dan kemampuan seseorang untuk membina hubungan dengan orang lain.

\section{b. Definisi Operasional}

Kecerdasan emosional dapat di ukur dengan menggunakan kuisioner tes EQ (Emotional Quetient) yang dikembangkan oleh Goleman dengan menggunakan dimensi kecerdasan emosional adalah 1. Mengenali Emosi Diri, 2. Mengelola Emosi , 3. Memotivasi Diri, 4. Mengenali Emosi Orang Lain, 5. Membina Hubungan Orang Lain. Tes tersebut sudah banyak digunakan oleh penelitian sebelumnya untuk mengukur 
EQ, diantaranya adalah penelitian yang berjudul, Pengaruh Kecerdasan Emosional Pemimpin Terhadap Kinerja dan Loyalitas Karyawan di PT Riau Andalan Pulp and Paper Bisnis Unit Riau Fiber, dan Pengaruh Kecerdasan Emosional dan Kecerdasan Spiritual Terhadap Kinerja Karyawan Pada LBPP-LIA Palembang, serta dilembaga/psikologi: fakultas ilmu administrasi Universitas Katolik Indonesia Atma Jaya, Psikologi Universitas Persada Indonesia Y.A.I.

\section{HASIL PENELITIAN DAN PEMBAHASAN}

\section{Data Intensi Berwirausaha}

Data mengenai intensi berwirausaha yang menjadi variabel Y. Data tersebut merupakan data primer yang diperoleh melalui pengukuran kuesioner dengan skala likert sebanyak 24 butir pertanyaan diisi oleh 123 responden yang berasal dari kelas XI jurusan Adm. Perkantoran, Akuntansi, dan Pemasaran di SMK Negeri 44 Jakarta.

Berdasarkan data yang terkumpul, diperoleh jumlah skor keseluruhan sebesar 11007, skor rata-rata sebesar 89,49, nilai terendah 69 , nilai tertinggi 115 , varians (S) sebesar 103,35, dan nilai standar deviasi (S) sebesar 10,26. Data yang didapatkan menghasilkan data tabel frekuensi variabel intensi berwirausaha yang dapat dilihat pada tabel dibawah ini. Berdasarkan perhitungan data rentang sebesar 46, interval sebesar 8 dan panjang kelas sebesar 6.

\section{Data Kecerdasan Emosional}

Data mengenai kecerdasan emosional yang menjadi variabel $X$. Data tersebut merupakan data kuesioner tes EQ yang dikembangkan oleh Goleman dengan menggunakan empat dimensi kecerdasan emosional, dalam buku Kiat Jitu Taklukan Psikotes sebanyak 30 butir pertanyaan diisi oleh 123 responden yang berasal dari kelas XI jurusan Adm. Perkantoran, Akuntansi, dan Pemasaran di SMK Negeri 44 Jakarta.

Berdasarkan data yang terkumpul diperoleh data kecerdasan emosional dengan jumlah skor keseluruhan sebesar 7043, rata-rata sebesar 57,26, nilai terendah 36, nilai tertinggi 79, varians (S) sebesar 63,87, dan standar deviasi (S) sebesar 7,99. Data yang didapatkan menghasilkan data tabel frekuensi variabel kecerdasan emosional yang dapat dilihat pada tabel dibawah ini. Berdasarkan perhitungan data rentang sebesar 43, interval sebesar 8 dan panjang kelas sebesar 6 .

\section{Pengujian Hipotesis \\ Persamaan Regresi}

Persamaan regresi yang digunakan adalah regresi linier sederhana, pengujian hipotesis ini bertujuan untuk mengetahui apakah terdapat hubungan diantara variabel $\mathrm{X}$ dan $\mathrm{Y}$ atau sebaliknya. Dari perhitungan yang dilakukan, diperoleh persamaan regresi linier $\mathrm{Y}=$ $58,04+0,55 X$, dimana $\mathrm{a}=58,04$ dan $\mathrm{b}=$ 0,55 .

Persamaan regresi tersebut menunjukkan bahwa setiap kenaikan 1(satu) skor kecerdasan emosional (X) dapat menyebabkan kenaikan intensi berwirausaha (Y) sebesar 0,55 pada konstanta 58,04

\section{Uji Persyaratan Analisis}

\section{a. Uji Normalitas Galat Taksiran}

Pengujian normalitas data digunakan untuk mengetahui apakah galat taksiran $\mathrm{Y}$ dan $\mathrm{X}$ berdistribusi normal atau tidak. Pengujian galat taksiran dengan menggunakan uji liliefors pada taraf signifikan $(\mathrm{a}=0,05)$ untuk sampel sebanyak 123 siswa, dengan kriteria pengujian data berdistribusi normal, 
apabila Ltabel dan jika sebaliknya maka galat taksiran regresi $\mathrm{Y}$ atas $\mathrm{X}$ tidak berdistribusi normal.

Dari hasil perhitungan uji normalitas data dapat diperoleh nilai 0,0798. Karena maka Ho diterima, artinya galat taksiran $\mathrm{Y}$ atas $\mathrm{X}$ berdistribusi normal dan penelitian dapat dilanjutkan pada pengujian hipotesis.

\section{b. Uji Linieritas Regresi}

Hasil perhitungan menunjukkan (Fh) 0,97

$<$ Ft 1,57 ini berarti Ho diterima dan model regresi linier.

\section{Uji Hipotesis}

\section{a. Uji Keberartian Regresi}

Berdasarkan hasil perhitungan Fo sebesar 27,13 dan untuk Ft adalah 3,92, sehingga dalam pengujian ini dapat disimpulkan bahwa (Fo) 27,13 > (Ft) 3,92 ini berarti Ho ditolak dan sampel dinyatakan memiliki regresi berarti.

\section{b. Uji Koefisien Korelasi}

Dengan mengacu pada tabel interpretasi nilai $r$, maka koefisien korelasi yang dihasilkan sebesar 0,4276 termasuk pada kategori sedang. Jadi terdapat hubungan yang sedang antara kecerdasan emosional dengan intensi berwirausaha.

\section{c. Uji Koefisien determinasi}

Dari hasil perhitungan diperoleh koefisien determinasi sebesar 18,28\%, sehingga dapat dikatakan bahwa variable intensi berwirausaha ditentukan oleh variabel kecerdasan emosional sebesar 18,28\% dan sisanya dipengaruhi oleh faktor lain.

\section{Pembahasan}

Berdasarkan hasil penelitian di atas, hasil yang diperoleh menunjukkan bahwa nilai kooefisien dari model persamaan regresi dapat diartikan bahwa setiap kenaikan satu variabel $X$ (kecerdasan emosional) akan menaikkan variabel $Y$ (intensi berwirausaha). Data yang digunakan dalam model regresi adalah berdistribusi normal, berbentuk linier dan berarti.

Hasil penelitian di atas juga menunjukkan bahwa adanya hubungan positif antara kecerdasan emosional dengan intensi berwirausaha. Hal ini dapat dilihat dari $\mathrm{t}$ hitung lebih besar dari $\mathrm{t}$ tabel $(5,20>1,645)$ yang menandakan adanya hubungan yang signifikan antara kecerdasan emosional dengan intensi berwirausaha. Pengajuan hipotesis ini telah dibuktikan dalam penelitian sebelumnya oleh Irene Paulina dan Wardoyo (2012) menyebutkan bahwa dengan memiliki kecerdasan emosi, seseorang akan mampu mengenali dirinya dan kemampuan dirinya yang dapat menimbulkan niatan (intensi) seseorang untuk melakukan suatu jenis usaha.

Senada dengan Dalam penelitian Povilas Zakarevicius and Aurimas Zuperka (2010) menyatakan "On the basis of the attitudes of the mentioned authors the assumption may be done, that emotional intelligence of an individual is an important element as the capability of entrepreneurial intentions diartikan Atas dasar sikap penulis mengasumsikan bahwa kecerdasan emosional seorang individu merupakan elemen penting sebagai kemampuan niat kewirausahaan. Kecerdasan emosional merupakan fondasi yang berfungsi untuk dapat mengarahkan setiap individu dalam menjalani kehidupan. Siswa yang cerdas emosi adalah siswa yang diharapkan mampu menyadari emosi-emosi dengan tepat dan mampu memahami perubahan emosi sekecil apapun, dapat memotivasi diri sendiri dengan baik, memiliki sikap optimis, tidak mudah putus asa, sabar, tabah, tangguh, memiliki rasa empati terhadap orang lain dan mampu menjalin hubungan sosial yang baik dengan orang lain. Hal ini berpengaruh terhadap intensi berwirausaha seseorang, karena menurut 
Goleman (2005) untuk menjadi seorang wirausaha tidak semata memerlukan intelegensi (IQ) saja, namum dibutuhkan pula Emotional quotient atau kecerdasan emosi.

Dari pendapat di atas, dapat disimpulkan bahwa kecerdasan emosional yangdimiliki seseorang siswa dapat mempengaruhi intensi berwirausaha siswa. Dimana untuk menjadi seorang wirausaha harus memiliki kecerdasan emosi yang baik dengan cara mengatasi emosi yang timbul dalam diri, memotivasi diri sendiri dan pantang menyerah.

Bentuk hubungan antara variabel kecerdasan emosional dengan intensi berwirausaha siswa kelas XI Jurusan Adm. Perkantoran, Akuntansi, dan Pemasaran SMK Negeri 44 Jakarta memiliki persamaan regresi $\mathrm{Y}=58,04+0,55 \mathrm{X}$. Persamaan regresi tersebut dapat dimaknai bahwa setiap kenaikan satu skor pada kecerdasan emosional (X) akan mengakibatkan peningkatan intensi berwirausaha (Y) sebesar 0,55 pada konstanta 58,04.

Besarnya hubungan variabel kecerdasan emosional pada siswa dengan intensi berwirausaha siswa dapat diketahui dengan melihat hasil perhitungan uji koefisien determinasi sebesar 18,28\% yang berarti bahwa tingkat intensi berwirausaha siswa kelas XI Jurusan Adm. Perkantoran, Akuntansi, dan Pemasaran SMK Negeri 44 Jakarta ditentukan oleh kecerdasan emosional.

Dari beberapa teori yang ada, dapat dipahami bahwa semakin baik kecerdasan emosional seorang siswa maka semakin tinggi intensi berwirausahanya. Demikian juga sebaliknya, semakin rendah kecerdasan emosional seorang siswa maka semakin rendah pula intensi berwirausahanya. Namun perlu diingat bahwa kecerdasan emosional bukan satu-satunya hal yang berpengaruh pada intensi berwirausaha. Terdapat hal lain yang dapat mempengaruhinya. Beberapa hal tersebut antara lain keterbatasan modal, kurang percaya diri, latar belakang keluarga yang bukan wirausaha dan lain-lain.

menyadari

Dalam penelitian ini, peneliti keterbatasan-keterbatasan menyebabkan tingkat keakuratan peneltitian ini tidak sepenuhnya mutlak. Adanya keterbatasan-keterbatasan yang peneliti alami dalam meneliti hubungan kecerdasan emosional dengan intensi berwirausaha adalah sebagai berikut:

1. Terbatasnya variabel yang diteliti. Penelitian ini hanya melibatkan satu variabel $X$ saja yang berakibat pada variabel Y. karena penelitian ini hanya ingin melihat hubungan antara kecerdasan emosional dengan intensi berwirausaha.

2. Hasil dari penelitian hanya berlaku pada SMK Negeri 44 Jakarta dan tidak dapat digeneralisasikan pada sekolah lainnya, karena setiap responden memiliki karakteristik yang berbeda.

3. Tingkat intensi berwirausaha yang diperoleh hanya berdasarkan pengukuran pada saat penelitian, jadi tingkat intensi berwirausaha ini belum tentu sama jika dilakukan pengukuran kembali.

4. Keterbatasan waktu, biaya, dan tenaga dalam menyelesaikan penelitian ini, sehingga intensitas penelitian tidak selancar yang diharapkan.

\section{KESIMPULAN DAN SARAN Kesimpulan}

Berdasarkan hasil analisis data penelitian tentang Hubungan Kecerdasan Emosional dengan Intensi Berwirausaha Siswa kelas XI di SMK Negeri 44 Jakarta, maka peneliti dapat mengambil kesimpulan sebagai berikut: 
1. Kecerdasan emosional merupakan kemampuan seseorang untuk mengenali emosi diri, mengelola emosi, memotivasi diri, mengenali emosi orang lain (empati), dan kemampuan untuk membina hubungan dengan orang lain.

2. Intensi berwirausaha merupakan keinginan dan keputusan individu untuk menjadi wirausahawan dengan cara memulai usaha serta menentukan strategi yang akan dilakukan dalam memulai usaha tersebut.

3. Terdapat hubungan yang positif dan signifikan antara kecerdasan emosional dengan intensi berwirausaha siswa.

4. Intensi berwirausaha siswa dipengaruhi oleh kecerdasan emosional sebesar $18,28 \%$, sedangkan sisanya dipengaruhi oleh faktor lain di luar dari variabel dalam penelian yang digunakan. Maka dari itu, dapat disimpulkan dalam penelitian ini bahwa semakin tinggi kecerdasan emosional yang dimiliki siswa maka semakin tinggi pula intensi berwirausaha nya, begitu juga sebaliknya, semakin rendah kecerdasan emosional yang dimiliki oleh siswa maka semakin rendah intensi berwirausahanya.

\section{Saran}

Berdasarkan kesimpulan dan implikasi yang dikemukakan di atas, saran-saran yang dapat diberikan peneliti adalah:

1. Untuk meningkatkan intensi berwirausaha siswa SMK Negeri 44 Jakarta hendaknya dalam setiap mata pelajaran kewirausahaan diselipkan pengetahuan psikologi tentang diri serta pengembangan motivasi. Dengan demikian akan memacu siswa untuk memiliki intensi berwirausaha

2. Untuk siswa yang memiliki kecerdasan emosional rendah dimana mereka belum bisa mengendalikan emosi dalam diri mereka sehingga mereka kurang mampu bekerja dengan efektif, kurang bisa motivasi dirinya sendiri, tidak optimis atas apa yang mereka lakukan, untuk kedepannya seiring bertambahnya usia mereka maka diharapkan mereka sudah mampu mengelola emosi mereka dengan baik, memiliki motivasi yang kuat serta dapat membina hubungan yang bai dengan orang lain.

3. Untuk guru, diharapkan dapat memotivasi siswa untuk menumbuhkan keinginan berwirausaha. Bisa dengan cara mengundang narasumber seorang pengusaha ke sekolah, memberi tugas-tugas lapangan (wawancara kepada pengusaha sukses), memberi tugas mandiri (membuat rencana usaha), melakukan magang di usaha-usaha kecil menengah untuk mempelajari persiapan dan pelaksanaan dalam berwirausaha. Dengan demikian, setelah lulus para siswa akan memiliki wawasan dunia usaha dan mempunyai keinginan untuk berwirausaha.

4. Untuk peneliti selanjutnya, diharapkan dapat memperluas wilayah penelitian selain di SMK Jurusan Adm. Perkantoran, Akuntasi, dan Pemasaran, menambah variabel lain diluar variabel penelitian yang sudah ada dan dapat menggunakan hasil penelitian ini untuk mengetahui perubahan perilaku berwirausaha siswa dimasa yang akan datang berdasarkan persentase intensi berwirausaha pada penelitian ini.

\section{DAFTAR PUSTAKA}

Ajen, Icek. Attitudes Personality and Behavior 2th Edition. Buckingham: Open University Press. 2005

Borch, Odd Jarl. et al. Entrepreneurship Research in Europe: Evolving Concepts and Processes. USA: Edward Elgar Publishing. 2011

Brice, JR, Jeff. The Role of Personality 
Dimensions on The Formation of Entrepreneurial Intentions. New York. Hofstra University. 2003

Choo, Stephen dan Melvin Wong. Entrepreneurial Intention: Triggers And Barriers to New Venture Creations In Singapore. Singapore Management Review 28 (2) 2006

Darmawan, Indra. Kiat Jitu Taklukkan Psikotes. Yogyakarta: Pustaka Widyatama. 2008

Dehkordi, Ali Mobini. et al. International Journals of Business and Social Science. Vol. 3. No. 13, July 2012 : 286-296

Finni, Riccardo. The Foundation of Entrepreneurial Intention. Paper to be presented at the Summer Conference. 2009

Goleman, Daniel. Kecerdasan Emosi Untuk Mencapai Puncak Prestasi (terjemah). Jakarta: Gramedia. 2005

Hisrich, Robert D, et al. Entrepreneurship edisi 7. Jakarta: Salemba 4. 2010

Husein, Umar. Metode Penelitian untuk Skripsi dan Tesis Bisnis edisi kedua. Jakarta: PT Rajagrafindo persada. 2009.

Linan, Fransisco dan Yi Wen Chen. Testing The Entrepreneurial Intention Model On Two-Country Sample. departemen d'economica deI'empressa. Spain, Juli 2006

Paulina, Irene dan Wardoyo. Jurnal Dinamika Manajemen. Vol. 3. No. 1, Maret 2012 : 1-10

Saefullah. Psikologi Perkembangan
Pendidikan. Bandung: CV Pustaka Setia. 2012

Sarwoko, Endi. Kajian empiris Entrepreneur Intention Mahasiswa. Jurnal Ekonnomi Bisnis Th. 16 No. 2, Juli 2011

Satiadarma, Monty P \& Fidelis E Waruwu. Mendidik Anak Dengan Kecerdasan. Jakarta: Pustaka Populer Obor. 2003

Sugiyono. Metode Penelitian Kuantitatif Kualitatif dan R\&D. Bandung: Alfabeta. 2009

Suharsimi, Arikunto. Manajemen Penelitian. Jakarta: Rineka Cipta. 2005

Sunar P, Dwi. Edisi Lengkap Tes IQ, EQ, dan SQ. Jogjakarta: Flash Books. 2010

Sunarya, PO Abas et al. Kewirausahaan. Yogyakarta: CV ANDI. 2011

Uno, Hamzah. B. Orientasi Baru dalam Psikologi Pembelajaran. Jakarta: PT.Bumi Aksara. 2008.

Zakarevicius, Povilas and Aurimas Zuperka. Economics and Management Journals. 2010. 15: 865-873 